\title{
Effects of reduced glutathione therapy on chronic hepatitis B
}

\author{
LI QIAN ${ }^{l}$, WENJUN WANG ${ }^{l}, Y^{\prime}$ AN ZHOU ${ }^{1}$, JIANXIN MA ${ }^{2}$
}

'Department of Clinical Laboratory, The Second People's Hospital of Lianyungang, Haizhou, China

${ }^{2}$ Department of Tumour Radiotherapy, The Second People's Hospital of Lianyungang, Haizhou, China

\begin{abstract}
Developed chronic hepatitis $B(C H B)$ causes death in approximately one million patients every year. Therefore, natural drugs with high therapeutic efficacy and minimal side effects must be developed for CHB treatment. This study aimed to relate the therapeutic effects of glutathione on CHB. A total of 104 $C H B$ patients were randomly divided into two groups: the control group, which received an intravenous drip of $0.4 \mathrm{~g}$ of inosine injection with $250 \mathrm{ml}$ of $5 \%$ glucose once a day for eight weeks, and the treatment group, which received an intravenous drip of $1200 \mathrm{mg}$ of glutathione on the basis of the treatment of the control group. Glutathione treatment decreased the serum levels of asparaginic acid transaminase, alanine aminotransferase, total bilirubin, total bile acids, haluronic acid, collagen IV, laminin, transforming growth factor- $\beta_{1}$, tumour necrosis factor- $\alpha$, interleukin-6, and interleukin- 8 , compared with the control group. The results indicate that glutathione treatment can improve liver function and inhibit inflammation and hepatic fibrosis in CHB patients.
\end{abstract}

Key words: hepatitis B, inflammation, immunology, microbiology.

(Cent Eur J Immunol 2017; 42 (1): 97-100)

\section{Introduction}

Approximately two billion people worldwide are infected by hepatitis B virus (HBV), and more than 240 million of them have developed chronic hepatitis $\mathrm{B}(\mathrm{CHB})$, which causes death in approximately one million patients every year $[1,2]$. Interferon and nucleoside analogues are the standard treatment methods, but these strategies have limited efficacy and severe side effects [3]. Therefore, natural drugs with high therapeutic efficacy and minimal side effects must be developed.

Reduced glutathione (GSH), the most abundant non-enzymatic antioxidant present in mammalian cells, is the main intracellular defence mechanism against oxidative stress [4]. During inflammatory processes, the cells of the immune system are exposed to large amounts of free radicals and toxic compounds; hence, these cells need an efficient glutathione system to scavenge the free radicals and toxic compounds that can otherwise disturb immune functions [5, 6]. Moreover, glutathione reduces the activation of nuclear factor $\kappa \mathrm{B}(\mathrm{NF}-\kappa \mathrm{B})$ and inhibits the synthesis of interleukin 6 (IL-6), IL-8, and tumor necrosis factor $\alpha$ (TNF- $\alpha$ ) [7]. Glutathione plays an important role in the repair of liver injury caused by virus, alcohol, drugs, and trauma [8-13]. However, data regarding the treatment effect of GSH on CHB are limited.
The present study investigated the treatment effect of GSH on CHB for the first time. Serum levels of asparaginic acid transaminase (AST), alanine aminotransferase (ALT), total bilirubin (TBil), total bile acids (TBA), haluronic acid (HA), collagen IV (C-IV), laminin (LN), transforming growth factor- $\beta_{1}$ (TGF- $\left.\beta_{1}\right)$, TNF- $\alpha$, IL- 6 , and IL-8 were all monitored.

\section{Material and methods}

\section{Ethics statement}

This study was approved by the Ethics Committee of The Second People's Hospital in Lianyungang, China. The participants provided verbal informed consent to participate in this study, and each consent was recorded in an electronic spreadsheet.

\section{Clinical data}

The CHB patients (104 cases) who participated in the experiments were selected from January 2014 to December 2014. The participants presented varying degrees of $\mathrm{CHB}$, either hepatitis B eAntigen ( $\mathrm{HBeAg}$ )-positive or -negative, without advanced liver disease.

The inclusion criteria for the patients in this study were: (1) HBV DNA of $\geq 20,000 \mathrm{IU} / \mathrm{ml}$ if $\mathrm{HBeAg}$-posi-

Correspondence: Yan Zhou, Department of Clinical Laboratory, The Second People's Hospital of Lianyungang, 41 East Hailian Road, Haizhou, 222006, China, tel. +86 518 85776016, fax: +86518 85775003, e-mail: zhouylyg@163.com Submitted: 30.12.2015; Accepted: 25.04.2016 
tive and $\geq 2000 \mathrm{IU} / \mathrm{ml}$ if HBeAg-negative, (2) alanine aminotransferase (ALT) of $>54$ and $\leq 400 \mathrm{U} / 1$ for men and $>36$ and $\leq 300 \mathrm{U} / 1$ for women, and (3) creatinine clearance rates of $\geq 70 \mathrm{ml} / \mathrm{min}$, as calculated using the Cockcroft-Gault equation [1].

\section{Exclusion criteria}

Any patient with one of the following conditions was excluded from participating in this study: (1) bridging fibrosis or cirrhosis as confirmed by liver biopsy or Fibroscan (P8 kPa) within 12 months prior to screening, (2) history of clinical hepatic decompensation, (3) evidence of hepatocellular carcinoma, (4) significant renal, autoimmune, or bone disease, (5) thyroid dysfunction, and (6) co-infection with HIV, HCV, or hepatitis D virus.

\section{Study design}

A total of $104 \mathrm{CHB}$ patients were randomly divided into two groups by using the stratified block randomisation method: the control group, which received an intravenous drip of $0.4 \mathrm{~g}$ of inosine injection with $250 \mathrm{ml}$ of $5 \%$ glucose once a day for eight weeks, and the treatment group, which received an intravenous drip of $1200 \mathrm{mg}$ of glutathione on the basis of the treatment of the control group.

\section{Data collection}

Data regarding patient demographics (sex, age at baseline, height, weight, and race), date of first dose, laboratory values for ALT and AST, and HBV virology, such as hep-

Table 1. Baseline characteristics of the 104 study patients

\begin{tabular}{|c|c|c|}
\hline Characteristic & $\begin{array}{l}\text { Control group } \\
\quad(n=52)\end{array}$ & $\begin{array}{l}\text { Treatment group } \\
\qquad(n=52)\end{array}$ \\
\hline Age (years) & $43.2(25-67)$ & $43.5(26-68)$ \\
\hline Sex (male/female) & $36 / 16$ & $35 / 17$ \\
\hline $\mathrm{AST}, \mathrm{IU} / \mathrm{1}^{\mathrm{a}}$ & $61.4(71.2)$ & $61.2(72.8)$ \\
\hline $\mathrm{ALT}, \mathrm{IU} / \mathrm{l}^{\mathrm{b}}$ & $69.2(166.2)$ & $69.6(171.4)$ \\
\hline HBV DNA, $\log _{10} \mathrm{IU} / \mathrm{ml}$ & $4.09(1.29)$ & $4.07(1.26)$ \\
\hline HBeAg positive & $44(84.6 \%)$ & $43(82.7 \%)$ \\
\hline \multicolumn{3}{|c|}{$\begin{array}{l}\text { Values are expressed as median (range) or mean (SD) } \\
\text { AST - aspartate aminotransferase; } A L T \text { - alanine aminotransferase; } H B V- \\
\text { hepatitis B virus; } H B e A g-\text { hepatitis Be antigen. } \\
{ }^{2} A S T \text { upper limit of normal was defined as } 40 \mathrm{IU} / \\
{ }^{b} A L T \text { upper limit of normal was defined as } 40 \mathrm{IU} /\end{array}$} \\
\hline
\end{tabular}

atitis B surface antigen (HBsAg) level, hepatitis B surface antibody (anti-HBs), HBV DNA level, HBV genotype, and $\mathrm{HBeAg}$ status were all collected at baseline. Liver function indexes were detected using a multifunctional automatic biochemical analyser. Levels of HA, C-IV, and LN were detected using a radio immunoassay kit purchased from the Shanghai Naval Medical Research Institute. Moreover, levels of TGF- $\beta_{1}$, IL- 6 , IL-8, and TNF- $\alpha$ were determined using the method of Kria, Ohira and Amemiya [14].

\section{Statistical analysis}

All data were presented as mean \pm SD. Statistical analysis was performed using Statgraphics Centurion XV Version 15.1.02. Multi-factor ANOVA with posterior multiple range tests was used to determine significant differences between the two groups.

\section{Results}

Between January and December 2014, 194 patients were screened and 104 were selected for treatment at The Second People's Hospital in Lianyungang. The baseline characteristics of the $104 \mathrm{CHB}$ patients are shown in Table 1 . There were no significant differences in the data between the control and treatment groups $(p>0.05)$.

GSH treatment significantly improved liver function as indicated by the decreases in ALT, AST, TBil, and TBA levels ( $p<0.05$, Table 2$)$, as well as reduction in hepatic fibrosis indicated by the decreases in HA, C-IV, LN, and TGF- $\beta_{1}$ levels ( $p<0.05$, Table 3 ), and decreased serum cytokine levels including TNF- $\alpha$, IL- 6 , and IL-8 levels $(p<0.05$, Table 4).

\section{Discussion}

Liver inflammation, cell apoptosis, liver regeneration, and fibrous tissue formation are the main mechanisms of the development of chronic hepatitis to liver cirrhosis, in which cytokines play an important role. In vivo studies showed that TGF- $\beta_{1}$ and TNF- $\alpha$ serve important functions in inflammation, cell apoptosis, regeneration, and fibrosis of the liver. IL- 6 and IL- 8 are the main inflammatory cytokines in vivo. Hepatitis B virus infection can activate the immune system, inducing the synthesis of numerous TNF- $\alpha$, which can also cause the synthesis of a large num-

Table 2. The changes in liver function indexes including alanine aminotransferase (ALT), asparaginic acid transaminase (AST), and total bilirubin (TBil) and total bile acids (TBA) of chronic hepatitis B after treatment

\begin{tabular}{|c|c|c|c|c|}
\hline Group & $\begin{array}{c}\mathbf{A L T} \\
(\mathbf{U} / \mathbf{l})\end{array}$ & $\begin{array}{l}\text { AST } \\
(\mathbf{U} / \mathbf{l})\end{array}$ & TBil ( $\mu \mathrm{mol} / \mathrm{l})$ & $\begin{array}{c}\text { TBA } \\
(\mu \mathrm{mol} / \mathrm{l})\end{array}$ \\
\hline Control group & $47.3(95.04)^{\mathrm{a}}$ & $46.1(49.72)^{\mathrm{a}}$ & $58.2(22.34)^{\mathrm{a}}$ & $44.7(12.09)^{\mathrm{a}}$ \\
\hline Treatment group & $34.8(92.35)^{\mathrm{b}}$ & $39.4(42.06)^{b}$ & $46.1(13.82)^{\mathrm{b}}$ & $35.8(11.73)^{b}$ \\
\hline
\end{tabular}

Values are expressed as mean (SD). Means with different superscript letters within a row indicate significant differ 
Table 3. The changes in serum liver fibrosis indexes including haluronic acid (HA), collagen IV (C-IV), laminin (LN), and transforming growth factor- $\beta_{1}\left(\right.$ TGF- $\left.\beta_{1}\right)$ of chronic hepatitis B after treatment

\begin{tabular}{lcccc}
\hline Group & $\begin{array}{c}\text { HA } \\
(\mathbf{n g} / \mathbf{l})\end{array}$ & $\begin{array}{c}\text { C-IV } \\
(\mathbf{n g} / \mathbf{l})\end{array}$ & $\begin{array}{c}\text { LN } \\
(\mathbf{n g} / \mathbf{l})\end{array}$ & $\begin{array}{c}\text { TGF- } \boldsymbol{\beta} \mathbf{1} \\
(\mathbf{n g} / \mathbf{l})\end{array}$ \\
\hline Control group & $174.9(38.53)^{\mathrm{a}}$ & $238.1(109.82)^{\mathrm{a}}$ & $142.6(76.09)^{\mathrm{a}}$ & $185.7(78.16)^{\mathrm{a}}$ \\
\hline Treatment group & $91.4(24.17)^{\mathrm{b}}$ & $161.2(72.64)^{\mathrm{b}}$ & $104.5(64.86)^{\mathrm{b}}$ & $132.6(65.94)^{\mathrm{b}}$ \\
\hline \multicolumn{2}{l}{ Values are expressed as mean $(S D)$. Means with different superscript letters within a row indicate significant differences $(p<0.05)$}
\end{tabular}

Table 4. The changes in serum cytokines including tumour necrosis factor- $\alpha$ (TNF- $\alpha$ ), interleukin-6 (IL-6), and interleukin-8 (IL-8) levels of chronic hepatitis B after treatment

\begin{tabular}{lccc}
\hline Group & $\begin{array}{c}\text { TNF- } \alpha \\
(\boldsymbol{\mu g} / \mathbf{l})\end{array}$ & $\begin{array}{c}\text { IL-6 } \\
(\mathbf{p g} / \mathbf{m l})\end{array}$ & $\begin{array}{c}\text { IL-8 } \\
(\mathbf{p g} / \mathbf{m l})\end{array}$ \\
\hline Control group & $29.3(5.03)^{\mathrm{a}}$ & $86.4(53.79)^{\mathrm{a}}$ & $39.5(8.86)^{\mathrm{a}}$ \\
\hline Treatment group & $21.6(3.94)^{\mathrm{b}}$ & $59.1(39.61)^{\mathrm{b}}$ & $23.7(6.13)^{\mathrm{b}}$ \\
\hline Values are expressed as mean $(S D)$. Means with different superscript letters within a row indicate significant differences $(p<0.05)$
\end{tabular}

ber of IL-6 and IL-8, thereby promoting liver inflammation and liver cell damage. The serum levels of AST, ALT, TBil, and TBA in CHB indicate liver function. Therefore, the increased serum levels of AST, ALT, TBil, TBA, HA, C-IV, LN, TGF- $\beta$, TNF- $\alpha$, IL- 6 , and IL- 8 CHB suggest that these parameters can reflect the degrees of liver inflammation and fibrosis.

$\mathrm{NF}-\kappa \mathrm{B}$ transcription factor family, which plays an important role in cell growth, differentiation, necrosis, and apoptosis, is widely involved in the pathogenesis of liver cell inflammatory reaction in viral hepatitis and thus is the key link of the inflammatory reaction $[15,16]$.

In normal cells, $\mathrm{NF}-\kappa \mathrm{B}$ and its inhibitory protein $\mathrm{I}-\kappa \mathrm{B}(\mathrm{I} \kappa \mathrm{B})$ are combined in the cytoplasm. When cells are stimulated by external stimuli, such as viral infections and oxidative stress, I $\mathrm{B}$ is rapidly phosphorylated and degraded by $26 \mathrm{~S}$ proteasome, and then releases $\mathrm{NF}-\kappa \mathrm{B}$, subsequently binding the specific $\kappa \mathrm{B}$ sequence and initiating and regulating many gene transcriptions associated with immune inflammatory response [17]. Furthermore, $\mathrm{NF}-\kappa \mathrm{B}$ can induce many types of cytokines (such as IL-6, IL-8, and TNF- $\alpha$ ), adhesion molecules [intercellular cell adhesion molecules-1 (ICAM-1) and vascular cell adhesion molecule-1 (VCAM-1)], and gene expression of the reactive protein in acute phase. Simultaneously, NF- $\kappa \mathrm{B}$ plays an important role in the gene expression of various enzymes involved in the amplification and extension of inflammatory responses.

$\mathrm{NF}-\kappa \mathrm{B}$ can be activated by inflammatory cytokines and thus can regulate the expression level of these inflammatory cytokines, which in turn causes the $\mathrm{NF}-\kappa \mathrm{B}$ to be in a sustained activation state, induce the release of a large number of cytokines and mediators, and further lead to a cascade of inflammatory reactions [18].

GSH is a thiol consisting of glutamic acid, cysteine, and glycine. GSH can hinder the phosphorylation of IкB and subsequently reduce the activation of NF- $\kappa \mathrm{B}$, thereby controlling gene transcription and inhibiting the synthesis of IL-6, IL-8, and TNF- $\alpha$ [7]. Simultaneously, GSH can affect the expression of IL-2 receptors, reduce the binding of IL-2 receptors and their effector cells, promote the internalisation and degradation of IL-2, IL-8, and IL-6 in the effector cells, and reduce the activation of the effector cells [19]. GSH can decrease NF- $\kappa \mathrm{B}$ activation and inhibit the expression of NF- $\kappa \mathrm{B}$-dependent adhesion molecules, such as VCAM-1 and GSH, by improving the level of glutathione in the cells and reducing the following effects on cells: aggregation of particles and monocytes, and adhesion of target cells, to protect these target cells [20]. GSH and its precursors can be used as free radical scavengers, which can reduce the TNF- $\alpha$-mediated oxidative damage to cells, decrease the damage of endothelial cell permeability, and also activate IL-1 $\beta$ invertase-like apoptosis protease by inhibiting TNF- $\alpha$, thereby reducing the damage to the cell protein [21]. This clinical study shows that the serum levels of ALT, AST, TBil, TBA, HA, C-IV, LN, TGF- $\beta_{1}$, TNF- $\alpha$, IL-6, and IL-8 in CHB patients are significantly higher than those in healthy people.

Treatment with GSH can rapidly improve the ability of anti-oxidative stress and repair the membrane structure of liver cells, which is beneficial to the recovery of liver function in a short period of time, probably because the decreased GSH levels in CHB patients obtain an exogenous supplement. Thus, the metabolic disorder in liver cells adjusted timely. Furthermore, GSH can inhibit the synthesis of cytokines, reduce aggregation of the activated effector cells, prevent the activation of effector cells, and decrease the cytokine-induced damage to target cells with a promotion effect of cytokines on liver cell inflammation.

In conclusion, glutathione treatment decreased the serum levels of ALT, AST, TBil, TBA, HA, C-IV, LN, TGF- $\beta_{1}$, TNF- $\alpha$, IL-6, and IL-8 in CHB patients. Overall, the results indicate that GSH is a promising drug for $\mathrm{CBH}$ treatment. However, how long the productive effect 
of GSH will last remains undetermined in this study and should be investigated in the future.

The authors declare no conflict of interest.

\section{References}

1. Chan HL, Elkhashab M, Trinh H, et al. (2006): Association of baseline vitamin D levels with clinical parameters and treatment outcomes in chronic hepatitis B. J Hepatol 63: 10861092.

2. Lavanchy D (2004): Hepatitis B virus epidemiology, disease burden, treatment, and current and emerging prevention and control measures. J Viral Hepatitis 11: 97-107.

3. Uhl P, Fricker G, Haberkorn U, Mier W (2014): Current status in the therapy of liver diseases. Int J Mol Sci 15: 75007512.

4. Meister A, Anderson M (1983): Glutathione. Annu Rev Biochem 52: 711-760.

5. Dröge W, Schulze-Osthoff K, Mihm S, et al. (1994): Functions of glutathione and glutathione disulfide in immunology and immunopathology. Faseb J 8: 1131-1138.

6. Nakamura H, Nakamura K, Yodoi J (1997): Redox regulation of cellular activation. Annu Rev Immunol 15: 351-369.

7. Rahman I (2000): Regulation of nuclear factor-kappaB, activator protein-1, and glutathione levels by tumor necrosis factor-alpha and dexamethasone in alveolar epithelial cells. Biochem Pharmacol 60: 1041-1049.

8. Bilzer M, Baron A, Schauer R, et al. (2002): Glutathione treatment protects the rat liver against injury after warm ischemia and Kupffer cell activation. Digestion 66: 49-57.

9. Bhandari S, Agarwal MP, Dwivedi S, Banerjee B (2008): Monitoring oxidative stress across worsening Child Pugh class of cirrhosis. Indian J Med Sci 62: 444-451.

10. Kwon do Y, Jung YS, Kim SJ, et al. (2009): Impaired sulfur-amino acid metabolism and oxidative stress in nonalcoholic fatty liver are alleviated by betaine supplementation in rats. J Nutr 139: 63-68.

11. Sora T (1998): Effects of combined glutathione and ursodeoxycholic acid therapy on chronic hepatitis $\mathrm{C}$ unresponsive to interferon. J Med Soc Toho U 45: 331-338.

12. Salunga TL, Cui ZG, Shimoda S, et al. (2007): Oxidative stress induced apoptosis of bile duct cells in primary biliary cirrhosis. J Autoimmun 29: 78-86.

13. Yang H, Ramani K, Xia M, et al. (2009): Dysregulation of glutathione synthesis during cholestasis in mice: molecular mechanisms and therapeutic implications. Hepatology 49: 1982-1991.

14. Kria L, Ohira A, Amemiya T (1998): Growth factors in cultured pterygium fibroblasts: immunohistochemical and ELISA analysis. Graef Arch Clin Exp 9: 702-708.

15. Wang J, Huang Q, Chen M (2003): The role of NF-kappaB in hepatocellular carcinoma cell. Chinese Med J 116: 47-752.

16. Yu LL, Yu HG, Yu JP, Luo HS (2004): Nuclear factor-kappa $\mathrm{B}$ regulates cyclooxygenase-2 expression and cell proliferation inhuman colorectal carcinoma tissue. Exp Oncol 26: 40-47.

17. Kiernan R, Brčs V, Ng RW, et al. (2003): Post-activation turnoff of NF-KB-dependent transcription is regulated by acetylation of p65. J Biol Chem 278: 2758-2766.
18. Xavier RJ, Podolsky DK (2000): How to get along friendly microbes in hostile world. Science 289: 1483-1484.

19. Hu EB, Zhang DG (2004): Reductive glutathione and ischemia reperfusion injury. J Navy Gen Hosp 17: 231-234.

20. Desai A, Huang X, Warren JS (1999): Intracellular glutathione redox status modulates MCP-1 expression in pulmonary granulomatous vasculitis. Lab Invest 79: 837-847.

21. Liu B, Andrieu-Abadie N, Levade T, et al. (1998): Glutathione regulation of neutral sphingomyelinase in tumor necrosis factor-alpha-induced cell death. J Biol Chem 273: 1131311320. 